\title{
Political Dynasties and the Moderating Role of Good Public Governance
}

\author{
Dyah Setyaningrum ${ }^{1 *}$, Hidayah Asfaro Saragih ${ }^{2}$ \\ ${ }^{*}$ Corresponding author
}

\begin{abstract}
The purpose of this study is to investigate the phenomena of political dynasties in Indonesia and its effect on local government performance. Moreover, this study also examines the moderating role of good public governance on the relationship between political dynasties and local government performance. Political dynasties define as the condition where local government head/vice head has a family connection with the head/vice head from the previous period or in other local government or with the legislative member. We use paired matched sample from local government in Indonesia during 2010-2015. The result shows that political dynasties negatively affect local government performance. Good public governance is proven to weaken the negative effect of political dynasties on the local government performance. Indonesia's central government need to regulate the practice of political dynasty as it is proved to decrease local government performance and encourage implementation of good public governance to reduce the adverse effects of political dynasties.
\end{abstract}

Keywords: political dynasties, local government performance, good public governance

\begin{abstract}
Abstrak
Tujuan dari penelitian ini adalah untuk menginvestigasi fenomena dinasti politik di Indonesia serta pengaruhnya terhadap kinerja pemerintah daerah. Lebih lanjut, penelitian ini juga menguji efek moderasi dari tata kelola pemerintahan terhadap hubungan antar dinasti politik dan kinerja pemerintah daerah. Dinasti politik di definisikan sebagai sebuah kondisi dimana kepala/wakil kepala daerah memiliki hubungan kekerabatan dengan kepala/wakil kepala daerah dari periode sebelumnya atau dari pemerintah daerah lain atau dengan anggota legislatif. Penelitian ini menggunakan paired matched sample dari pemerintah daerah di Indonesia selama periode 2010-2015. Hasil penelitian menunjukkan bahwa dinasti politik berpengaruh negatif terhadap kinerja pemerintah daerah. Tata kelola pemerintahan terbukti dapat mengurangi pengaruh negatif dinasti politik terhadap kinerja pemerintah daerah. Pemerintah Indonesia perlu membuat regulasi atas praktik dinasti politik karena terbukti dapat menurunkan kinerja pemerintah daerah serta mendorong implementasi tata kelola pemerintahan untuk mengurangi dampak buruk dinasti politik tersebut.
\end{abstract}

Kata Kunci: dinasti politik, kinerja pemerintah daerah, tata kelola pemerintahan

JEL Code: D72, H11, H79

\section{How to Cite:}

Setyaningrum, D., \& Saragih, H. A. (2019). Political Dynasties and the Moderating Role of Good Public Governance. Signifikan: Jurnal Ilmu Ekonomi, Vol. 8(2), 135-144. doi: http://dx.doi.org/10.15408/sjie. v8i2.11636. 


\section{Introduction}

Indonesia has implemented regional autonomy for almost two decades. The impact of decentralization on various aspects in several countries has widely studied. In developed countries, decentralization is proven to reduce corruption (Fisman \& Gatti, 2002; Goel \& Nelson, 2011). While on the other, Lessmann \& Markwardt (2010) argue that decentralization can contribute to high levels of corruption. The phenomenon of political dynasty occurs in countries that implement democracy and decentralization, and it occurs both at the executive and legislative levels. Control by these local elites will have a negative impact on government performance. The political dynasty will reduce the level of regional financial accountability (Nuritomo \& Rossieta, 2014). It also negatively affect the management of public funds, hampering economic development and weaken the elections competitiveness (Asako et al., 2015). In the long run, political dynasties also threaten democracy and economic development (Querubin, 2013), centralize political power (Mendoza et al., 2012), and foster long-term clientelist relationships (George \& Ponattu, 2017). Control by local elites will also trigger corrupt practices by members of the ruling dynasty family (Mendoza et al., 2012).

Indonesia also experienced the phenomenon of a political dynasty. Latest data from Indonesian Corruption Watch shows that there are 58 regional heads with political dynasties backgrounds (ICW, 2017). Indonesian Corruption Watch mentions that those regional heads need to monitor as the political dynasties can create a conflict of interest and information asymmetry between local government and the stakeholders (ICW, 2017). Control by political dynasties will exacerbate local government performance shown by the misallocation of government spending. The opportunistic behavior of these dynastic politicians did through misuse of budgets and resources for the benefit of their constituents (George \& Ponattu, 2017).

Therefore, an effort should be made to reduce the negative impacts and increase the positive impact of regional autonomy. One of the efforts that have been made by the Indonesian central government to assess the success of regional autonomy is to evaluate the local government performance. At the end of the budget period, local government should submit local government financial report that consists of performance and conformity aspects. This performance evaluation needs to be done because it will provide feedback on the plan that had implemented (Chow et al., 1998). Other benefits to be gained from performance evaluation are as inputs to improve future government performance, improve efficiency and effectiveness in service delivery to communities, as inputs in decision making and resource allocation, and create public responsibility and improve institutional communication.

Implementation of good public governance believed can boost the positive impact of regional autonomy. Previous research shows that strong good public governance will improve the performance of local governments (Irmawati \& Pratolo, 2016; Yuniar \& Bambang, 2015), increase economic growth (Easterly \& Levine, 1997), and tax revenue (Ajaz \& Ahmad, 2010; Farooq et al., 2013). Moreover, Setyaningrum et al., (2017) found that higher good public governance is associated with lower corruption; and lower corruption is associated with high public service quality. The competent public governance can also weaken the inefficiency of government spending (Rossieta et al., 2017). The success of GPG implementation is 
inseparable from the inherent political aspect. Both legislative and executive bodies influence how the policy is making in the local government, which will then impact on the decision, including the implementation of good public governance. Previous research about political dynasty in Indonesia discusses the impact of political dynasty directly to local performance management (Nuritomo \& Rossieta, 2014). This study will test the moderating effect of good public governance on the relationship between political dynasty and local government performance. To the best of our knowledge, there is no previous research that examined this moderating effect. The existence of political dynasty reinforces the opportunistic behavior of agents to maximize their interest; however, a strong good public governance is expected to weaken the adverse effects of political dynasties on the local governments' performance.

This study aims to examine the influence of political dynasties on local government performance. Besides, this study also examined the role of GPG on the relationship between political dynasties and local government performance. The political dynasty is expected to have an adverse effect on local government performance, and GPG can weaken the negative effect of political dynasties on local government performance. This study contributes to the literature in several ways. First, this study investigates the phenomenon of political dynasties in Indonesia. The measurement of political dynasties not only when local government head/vice head has a family connection with head/vice head from the previous period (regeneration model) but also when local government head/vice head has a family connection with head/vice head in other local government (cross-regional model) or with legislative member both in Second, many previous studies have examined the direct effect of GPG on the performance of local government. This study will examine GPG as a moderating role that is expected to weaken the effect of political dynasties on the performance of local government. Third, GPG measurement is not only based on one principle but using GPG index based on the five best practice principles from Indonesia National Committee of Governance Policy, namely democracy, accountability, transparency, culture of law and fairness and equality (Komite Nasional Kebijakan Governance, 2008).

\section{Method}

The population in this study is all local government in districts and cities in Indonesia during 2010-2015. Purposive sampling is used to select the sample. The sampling criteria are local governments that have complete data from the year 2010-2015, which consists of local government performance score, political dynasty, GPG index, and all control variables. Data sources obtained from the official website of each local government, Ministry of Internal Affairs, Supreme Audit Agency, Ministry of Finance, and the Central Statistical Bureau. Due to the small amount local government with political dynasty (only $8 \%$ of the total population), then we use a paired sample approach. From 250 local governments with political dynasty, we select 250 local governments with non-political dynasty. The following criteria are used to select the paired sample: 1) Non-dynastic local government within the same province as dynastic local government, 2) Non-dynastic local government which has the same number of years of observation with dynastic local government, and 3) if both criteria met, then the local government with the best financial performance is selected. 
This study has two hypotheses, which are: 1) to test whether political dynasty has a negative relationship with local government performance and 2) to test whether good public governance can weaken the negative relationship between political dynasty and local government performance. The research model is as follow:

$$
\begin{aligned}
\text { PERF }_{i t}= & \propto_{0}+\propto_{1} D Y N_{i t}+\propto_{2} \text { SPEND }_{i t}+\propto_{3} \text { SIZE }_{i t}+\propto_{4} P A D_{i t}+\propto_{5} D E P E N D_{i t}+ \\
& \propto_{6} D \_T Y P E_{i t}+\propto_{7} A G E_{i t}+\varepsilon_{i t} \\
\text { PERF } & \beta_{0}+\beta_{1} D Y N_{i t}+\beta_{2} G P G_{i t}+\beta_{3} D Y N_{i t} * G P G_{i t}+\beta_{4} S P E N D_{i t}+\beta_{5} S_{I Z E_{i t}}+ \\
& \beta_{6} P A D_{i t}+\beta_{7} D E P E N D_{i t}+\beta_{8} D T Y P E_{i t}+\beta_{9} A G E_{i t}+\varepsilon_{i t}
\end{aligned}
$$

Where: PERFit is performance of local government $\mathrm{i}$ in year $\mathrm{t}$; DYNit is whether local government $\mathrm{i}$ is dynastic or not in year t; GPGit is good public governance index of local government $\mathrm{i}$ in year $\mathrm{t}$; SPENDit is spending of local government $\mathrm{i}$ in year $\mathrm{t}$; SIZEit is size of local government $\mathrm{i}$ in year $\mathrm{t}$; PADit is independency of local government $\mathrm{i}$ in year $\mathrm{t}$; DEPENDit is dependency of local government $\mathrm{i}$ in year $\mathrm{t}$; D_TYPEit is local government type; and AGEit is administrative age of local government $\mathrm{i}$ in year $\mathrm{t}$.

Political dynasty in this research is referring to Saragih (2018). Local government is classified practicing political dynasty when one of the three following condition met: 1) where local government head/vice head has a family connection with head/vice head from the previous period; 2) local government head/vice head has a family connection with head/vice head in other local government; 3) local government head/vice head has a family connection with legislative member both in the same/different areas. Good Public Governance Index is measured using five governance principles (democracy, transparency, accountability, the culture of law and fairness

\begin{tabular}{|c|c|}
\hline Variable & Measurement \\
\hline \multicolumn{2}{|l|}{ Dependent Variable } \\
\hline Local government performance (PERF) & Local government score released by Ministry of Internal Affairs \\
\hline \multicolumn{2}{|l|}{ Independent Variables } \\
\hline Political Dynasties (DYN) & 1 if local government is politically dynastic; 0 otherwise \\
\hline Good Public Governance (GPG) & $\begin{array}{l}\text { Good Public Governance Index from five governance } \\
\text { principles using Principle Component Analysis }\end{array}$ \\
\hline \multicolumn{2}{|l|}{ Control Variables } \\
\hline Local government spending (SPEND) & $\begin{array}{l}\text { Natural logarithm of total realization of local government } \\
\text { spending }\end{array}$ \\
\hline Local government size (SIZE) & Natural logarithm of local government's total assets \\
\hline Independency of local government (PAD) & Ratio of local income to total income of local government \\
\hline $\begin{array}{l}\text { Dependency of local government } \\
\text { (DEPEND) }\end{array}$ & Ratio of transfer income to total income of local government \\
\hline Type of local government (D_TYPE) & 1 if local government is city; 0 if local government is district \\
\hline Administrative age of local government (AGE) & Age of local government (in years) since its formation \\
\hline
\end{tabular}
and equity) of the public sector from The Indonesian National Committee of Governance Policy refer to Setyaningrum et al., (2017). The variable measurement presented in Table 1.

Table 1. Variables Measurement 


\section{Result and Discussion}

The total sample used in the analysis is 500 observations from the year 2010-2015. Descriptive statistics presented in Table 2. The average performance (PERF) score is 2.875 shows that the average performances of the municipalities/cities are high (high score ranging from 2 to 3). Using paired matched sample, the political dynasty variable (DYN) variable, dynastic and non-dynastic local governments have $50 \%$ proportion each. The political dynasty spread across 58 local governments in Indonesia and concentrated in 20 provinces and dominated in Java Island. Good public governance (GPG) shows an increasing trend over the years, although the average number is remaining low. Similar to Setyaningrum et al. (2017), the most significant improvement is in transparency and accountability.

Table 2. Descriptive Statistics

\begin{tabular}{cccccc}
\hline Variable & Obs & Mean & Std. Dev. & Min & Max \\
\hline PERF & 500 & 2.875 & 0.440 & 0.604 & 3.547 \\
DYN & 500 & 0.500 & 0.501 & 0.000 & 1.000 \\
GPG & 500 & 0.210 & 0.341 & -0.980 & 1.278 \\
SPEND & 500 & 27.839 & 0.594 & 25.841 & 29.630 \\
SIZE & 500 & 28.640 & 0.735 & 26.837 & 31.284 \\
PAD & 500 & 0.126 & 0.092 & 0.014 & 0.610 \\
DEPEND & 500 & 0.838 & 0.109 & 0.196 & 0.991 \\
D_TYPE & 500 & 0.216 & 0.412 & 0.000 & 1.000 \\
AGE & 500 & 50.202 & 20.072 & 4.000 & 65.000 \\
\hline
\end{tabular}

Note: PERF: Local government performance; DYN: Political Dynasties; GPG: Good Public Governance; SPEND: Local government spending; SIZE: Local government size; PAD: Local government independency; DEPEND: Local government dependency; D_TYPE: Local government type; AGE: Local government age.

${ }^{* * *}$ significant at $a=1 \%,{ }^{* *}$ significant at $a=5 \%,{ }^{*}$ significant at $a=10 \%$

The regression result for hypothesis 1 presents in Table 3. Hypothesis 1 stated that political dynasty has a negative effect on local government performance. Based on the regression result on Table 3, hypothesis 1 is supported or otherwise stated, the local government with political dynasty has worse performance than local government without political dynasty, in line with previous result by Asako et al., (2015), Mendoza et al., (2012), and Tusalem \& Pe-Aguirre (2013). They found that political dynasty weakens government performance and local economic performance. Political dynasties decrease the accountability of local financial management (Nuritomo \& Rossieta, 2014); hamper economic development and weaken power competitiveness of elections (Asako et al., 2015), deter better candidates to rule the government and low public funds management (Querubin, 2013). Moreover, Saragih (2018) also found that in dynastic local government, the opportunistic behavior occurs through misuse of total spending. 
Table 3. Regression Result Model 1

\begin{tabular}{|c|c|c|}
\hline Variables & Coefficients & $P>t$ \\
\hline CONS & -0.119 & 0.451 \\
\hline DYN & -0.307 & $0.000^{* * *}$ \\
\hline SPEND & 0.244 & $0.000^{* * *}$ \\
\hline SIZE & -0.127 & $0.000^{* * *}$ \\
\hline PAD & 0.290 & 0.132 \\
\hline DEPEND & -0.416 & $0.036^{* *}$ \\
\hline D_TYPE & 0.034 & 0.239 \\
\hline AGE & 0.006 & $0.000^{* * *}$ \\
\hline Prob > F & & 0.000 \\
\hline R-squared & & 0.416 \\
\hline
\end{tabular}

Note: PERF: Local government performance; DYN: Political Dynasties; GPG: Good Public Governance; SPEND: Local government spending; SIZE: Local government size; PAD: Own-Source Revenue; DEPEND: Local government dependency; D_TYPE: Local government type; AGE: Local government age.

${ }^{* * *}$ significant at $\alpha=1 \%,{ }^{* *}$ significant at $\alpha=5 \%,{ }^{*}$ significant at $\alpha=10 \%$

The result of hypothesis 2 presents in Table 4. The second hypothesis stated that good public governance would weaken the negative effect of political dynasty on the local governments' performance. The regression results in Table 4 shows that hypothesis 2 is supported. It shows the positive result of moderating variables between good public governance and political dynasty. The agency theory mentions that the agent will maximize the utility and self-interest, so it will not show optimum performance in carrying out its duties and responsibilities. The existence of political dynasty reinforces this opportunistic motive of such agents. However, strong good public governance is expected to weaken the negative effects of political dynasties on the local governments' performance. Good public governance will create reliable and responsible management that is in line with democratic principles, avoidance of budget miss allocations, and corruption prevention. Strong good public governance will improve the performance of local governments (Irmawati \& Pratolo, 2016), economic growth (Easterly \& Levine, 1997) and the level of tax revenues of a country (Ajaz \& Ahmad, 2010; Farooq et al., 2013). Moreover, good public governance on the quality has an indirect effect to public services through corruption; where strong good public governance can reduce corruption and local governments with a low level of corruption will get better public services (Setyaningrum et al., 2017). Good public governance can reduce the inefficiency of government spending or otherwise stated that public spending would be more ineffective in local government with poor governance (Rossieta et al., 2017). Good public governance will improve all aspects of democracy, transparency, accountability, the culture of law and fairness and equality that are expected to reduce the negative effect of political dynasty practices on the local governments' performance. 
Table 4. Regression Result Model 2

\begin{tabular}{|c|c|c|}
\hline Variables & Coefficients & $P>t$ \\
\hline CONS & 1.819 & $0.018^{* *}$ \\
\hline DYN & -0.274 & $0.000^{* * *}$ \\
\hline GPG & 0.273 & $0.000^{* * *}$ \\
\hline GPG*DYN & 0.166 & $0.037^{* *}$ \\
\hline SPEND & 0.136 & $0.002^{* *}$ \\
\hline SIZE & -0.089 & $0.005^{* *}$ \\
\hline PAD & 0.199 & 0.217 \\
\hline DEPEND & -0.408 & $0.034^{* *}$ \\
\hline D_TYPE & -0.003 & 0.476 \\
\hline AGE & 0.005 & $0.000^{* * *}$ \\
\hline Prob $>$ F & & 0.000 \\
\hline R-squared & & 0.4585 \\
\hline
\end{tabular}

Note: PERF: Local government performance; DYN: Political Dynasties; GPG: Good Public Governance; SPEND: Local government spending; SIZE: Local government size; PAD: Own Source Revenue; DEPEND: Local government dependency; D_TYPE: Local government type; AGE: Local government age.

${ }^{* * *}$ significant at $\alpha=1 \%,{ }^{* *}$ significant at $a=5 \%,{ }^{*}$ significant at $a=10 \%$

The negative effect of political dynasties such as lower local financial management accountability (Nuritomo \& Rossieta, 2014); worse economic development and lower competitiveness of elections will be reduced if local government has strong good public governance (Asako et al., 2015). Good public governance will improve democracy by increasing participation, transparency through use of Information Technology (Elbahnasawy, 2014) accountability through the follow up of audit recommendation (Setyaningrum \& Martani, 2018), culture of law through law enforcement, and fairness and equality through proper spending allocation (Rossieta et al., 2017). All these impacts of strong good public governance can reduce the negative effect of political dynasty on the local governments' performance.

Control variables from Model 1 and Model 2 show a consistent result. Total spending and administrative age of local government have a positive effect on local government performance. The higher the spending, the higher local governments performance (Saragih, 2018). High spending is allocated to increase public welfare and empower society to generate more revenue sources. The positive effect of administrative age shows that local government with longer age has better experience in running the government, and it will have a positive effect on performance.

The size and dependency have an adverse effect on local government performance. Local governments need sufficient resources and adequate facilities to provide excellent public services. Thus, the higher the size measured by, the more significant assets, the higher the performance. The central governments monitor what local government is doing. Thus it motivates the local government to increase their performance. The higher the dependence on 
the central government, the local governments have an incentive to provide better services to the public (Setyaningrum \& Martani, 2018). Based on descriptive statistics, the average of own-source revenue is relatively small (below 15\%); this may be the cause of the insignificant effect of this variable. The local government still relies on the source of income from the central government and does not optimize the potential income from their region. Type of local government shows does not affect local government performance. Cities and districts both have performance indicators that aim to improve the quality of community services, so regardless of the type, they will strive to perform best.

\section{Conclusion}

This study aims to investigate the effect of political dynasties on local government performance. This study also examined the moderating role of good public governance on the relationship between political dynasties and local government performance. The political dynasty is expected to have an adverse effect on local government performance, and excellent public governance can weaken the negative effect of political dynasties on local government performance. We use paired matched sample from local government (districts and cities) in Indonesia during 2010-2015. The result shows that political dynasties negatively affect local government performance. Good public governance is proven to weaken the negative effect of political dynasties on the local government performance. The political dynasty spread across 58 local governments in Indonesia and concentrated in 20 provinces and dominated in Java Island. The negative effect of the political dynasty has to be Indonesia's central government main concern. The central government needs to create a mechanism that limits the negative effect of this political dynasty. For example, enactment of the law that requires a one-period break for those who wants to run for an election after his family/relatives served as a local government head. The ministry of internal affairs can disclose politicians with the dynastic background, so voters have an opportunity to choose better candidates.

Furthermore, local governments are encouraged to implement good public governance since it can become a useful tool to reduce the adverse effects of political dynasties. Central and local governments should pay more attention to the quality of good governance and put more efforts to improve the aspects that relate to governance. Establishing a standard for all public services as well as the ease of doing business will improve democracy. Accountability can improve through improving audit opinion and performance report as well as report timeliness. Transparency can improve by maximizing the usage of information technology (e-government) in every public service such as e-procurement and e budgeting. Culture of law can improve by stronger law enforcement. Finally, fairness and equity can improve by giving the public the same right and access to public service.

There are some limitations of this study and recommendation for further studies. First, due to a limited number of local governments with political dynasty, we cannot perform additional analysis on which type of political dynasty that has the worst effect on performance. Further research can consider examining the different effect of each type of political dynasty. This result is essential for the regulator to establish the law to limit those practices. Second, 
the measurement of useful public governance index based on the subjective classification to five governance principles. Further study can consider complementing the index using benchmark from other countries best practices as well as judgments from the panel of expert.

\section{References}

Ajaz, T., \& Ahmad, E. (2010). The Effect of Corruption and Governance on Tax Revenues. The Pakistan Development Review, 49(4), 405-417.

Asako, Y., Iida, T., Matsubayashi, T., \& Ueda, M. (2015). Dynastic Politicians: Theory and Evidence from Japan. Japanese Journal of Political Science, 16(1), 5-32.

Chow, C. W., Ganulin, D., Haddad, K., \& Williamson, J. (1998). The Balanced Scorecard: A Potent Tool for Energizing and Focusing Healthcare Organization Management. Journal of Healthcare Management, 43(3), 263-273.

Easterly, W., \& Levine, R. (1997). Africa' S Growth Tragedy: Policies And Ethnic Divisions. The Quarterly Journal of Economics, 112(4), 1203-1250. https://doi.org/10/1162/ 003355300555466.

Elbahnasawy, N. G. (2014). E-Government, Internet Adoption, and Corruption: An Empirical Investigation. World Development, 57, 114-126. https://doi.org/ 10.1016/j. worlddev.2013.12.005.

Farooq, A., Shahbaz, M., Arouri, M., \& Teulon, F. (2013). Does Corruption Impede Economic Growth in Pakistan? Economic Modelling, 35, 622-633. https://doi.org/10.1016/j. econmod.2013.08.019.

Fisman, R., \& Gatti, R. (2002). Decentralization and Corruption: Evidence Across Countries. Journal of Public Economics, 83(3), 325-345. https://doi.org/10.1016/ S0047- 2727(00)00158-4.

George, S. E., \& Ponattu, D. (2017). Understanding the Economic Impacts of Political Dynasties: Evidence from India. Working Paper. Retrieved from https://sites.tufts.edu/ neudc2017/files/2017/10/paper_433.pdf

Goel, R. K., \& Nelson, M. A. (2011). Measures of Corruption and Determinants of US Corruption. Economics of Governance, 12(2), 155-176. https://doi.org/10.1007/ s10101-

ICW. (2017). Spreading The Spirit of Anti-Corruption. Annual Report 2017.

Irmawati, F. D., \& Pratolo, S. (2016). Pengaruh Kinerja Keuangan, Politik Dinasti, dan Kinerja Pemerintah Daerah Terhadap Akuntabilitas Pelaporan Keuangan Pemerintah Daerah Di Indonesia Tahun 2012-2013 (The Influence of Financial Performance, Dynasty Politics, and Local Government Performance Against Accountability for Local Government Financial Reporting in Indonesia in 2012-2013) . Working Paper. retrieved from: http://repository.umy.ac.id/handle/123456789/2756

Komite Nasional Kebijakan Governance. (2008). Pedoman Umum Good Public Governance Indonesia (The General Guidance of Indonesia Good Public Governance). Jakarta: Komite Nasional Kebijakan Governance 
Lessmann, C., \& Markwardt, G. (2010). One Size Fits All? Decentralization, Corruption, and the Monitoring of Bureaucrats. World Development, 38(4), 631-646. https://doi. org/j.worlddev.2009.11.003.

Mendoza, R. U., Beja, E. L., Venida, V. S., \& Yap, D. B. (2012). Inequality in Democracy: Insights from an Empirical Analysis of Political Dynasties in the 15th Philippine Congress. Philippine Political Science Journal, 33(2), 132-145.

Nuritomo, \& Rossieta, H. (2014). Politik Dinasti, Akuntabilitas, Dan Kinerja Keuangan Pemerintah Daerah Di Indonesia (Political Dynasties and Financial Performance of Regional Government in Indonesia). Working Paper. Universitas Atmajaya, Yogyakarta.

Querubin, P. (2013). Family and politics: Dynastic persistence in the Philippines. Quarterly Journal of Political Science, 11(2), 151-181.

Rossieta, H., Martani, D., \& Wardhani, R. (2017). Good Governance and The Impact of Government Spending on Performance of Local Government in Indonesia. International Journal of Public Sector Performance Management, 3(1), 77-87.

Saragih, H. A. (2018). Dinasti Politik dan Reelection sebagai Pemoderasi pada Hubungan antara Belanja Pemerintah Daerah Terhadap Kinerja Keuangan (Political Dynasty and Reelection as Moderating the Relationship between Local Government Expenditures on Financial Performance). (Unpublished Thesis). Depok: Universitas Indonesia

Setyaningrum, D., \& Martani, D. (2018). Determinants of Local Government Performance in Indonesia. Proceeding of the $6^{\text {th }}$ International Accounting Conference, 7-12. https:// doi.org/10.2991/iac-17.2018.2

Setyaningrum, D., Wardhani, R., \& Syakhroza, A. (2017). Good Public Governance, Corruption and Public Service Quality: Indonesia Evidence. International Journal of Applied Business and Economic Research, 15(19), 327-338.

Tusalem, R. F., \& Pe-Aguirre, J. J. (2013). The Effect of Political Dynasties on Effective Democratic Governance: Evidence from The Philippines. Asian Politics and Policy, 5(3), 359-386.

Yuniar, H. L., \& Bambang, J. (2015). Key Success Factor Good Government Governance Serta Pengaruhnya Terhadap Kinerja Pemerintah: Survey pada Pemerintah Kabupaten Gunungkidul (Key Success Factor of Good Government Governance and Its Impact on Government Performance: Survey of Gunungkidul Regency Government.). Maksimum, 5(1), 32-49. 